\title{
Learning Needs Analysis of 3D Stereoscopic Textbook: An empirical study of Primary School Pupils and Teachers in Science Learning
}

\author{
Dede Permana $^{1}$, Sarwanto $^{1}$, and Peduk Rintayati ${ }^{1}$ \\ ${ }^{1}$ Primary School Teacher Education, Postgraduate Programs Sebelas Maret University.
}

\begin{abstract}
This study is descriptive and explorative research which is aimed to find out the needs of students and teachers against the textbooks based 3D stereoscopic images towards the implementation of science learning based on curriculum 2013 framework design by using thematic learning concept. Because the learning process is conducted thematically, so the textbooks which used also is constructed thematically by integrating various concepts of subject. One of the subjects is science. The aims of this research is reached through observation, interview, and study of document . The finding of observation shows that the students get some problems in the interest to learns. This case appears while the students are doing activities which are not related to learning. Meanwhile, from the result of interview supported by the data of study to document, it is revealed that intregating thematically causes the implementation of science subject is not conducted in depth. Beside that, the teachers complain the usage of colorless thematical textbook, so the application of pictures in textbooks to illustrate the concept of science is not complete and it is not interesting, whereas the students of primay school rates 7 to 11 years old that is still in the phase of concrete operational thinking that require the textbook presenting concrete learning concepts. Based on the statements above, it is happened commonly if the students are not interested to learn. It concludes that thematical textbooks which is used nowdays have some weaknesses in presenting the learning concepts.
\end{abstract}

Keyword: Learning Needs, 3D Stereoscopic, Science Learning, Primary School.

\section{INTRODUCTION}

Natural Science is a learning program that is given from elementary school to university. According to Wisudawati and Sulistyowati [1], the characteristic of science learning is the study of factual phenomena, whether in reality or events and causal relationships. In the implementation of learning concept of animal and plant morphology, should be implemented in accordance with the nature of science learning for learning purposes that can be achieved.

To support the achievement of the nature of learning science need to use teaching materials as a source of learning. One of the teaching materials that can be used is textbooks. Situmorang [3] A good textbook should be packed attractively according to the subject and include pictures, illustrations, examples of problems or contextual cases sufficient to support teaching. Ardenghi \& Roth [4] the use of visual aids in textbooks is 
not only for illustrate something, but to help students understand scientific concepts, especially if the concept is still unknown (abstractly). Textbook is a book that contains knowledge derived from the basic competencies in the curriculum are systematically arranged for use by students. Textbooks are one of the important components in learning that can help smooth student learning. The development of innovative textbooks is important to improve students' character and learning outcomes.

This research is a preliminary part of research and development of science textbook based on 3D stereoscopic image. So this study aims to analyze the need for the development of science textbooks based on 3D Stereoscopic images used to help mastery the concept of science Analyzing needs is an important step in research and development study, because by doing needs analysis, product development will be in accordance with the required.

The focus of the analysis is the current textbook along with its weaknesses and constraints. The results of the research will be used as the basis in conducting research development of science textbooks based on 3D Stereoscopic images.

\section{RESEARCH METHODS}

The type of research is descriptive explorative research conducted in March to May 2017 in some elementary schools in Surakarta. The subjects of this research are teachers and students of grade IV of elementary school. This research is a needs analysis consisting of literature study and field study. The literature study was conducted by collecting a theoretical basic to analyze the development needs of textbook science based on 3D stereoscopic images. In the literature study the researchers also sought the source of writing in the form of articles, theses, dissertations relevant to this research and books that can be used as a basis for developing textbooks. Through literature study obtained information about the needs analysis in science learning in elementary school Surakarta. Other supporting literature supporting the research process is in the form of Syllabus and lesson plan (RPP). Then, field studies were conducted to collect data from schools.

Field studies were conducted in several elementary schools in Surakarta, such as SD Al Islam 1 Surakarta, SD N 2 Nayu and SD Muhammadiyah 6 Surakarta. The research technique used observation, interview and document study. Observations technique made for see the condition of learning science, observation sheet covering matters as follows; (1) students' views and observations during science classroom learning; and (2) constraints gained during science teaching in elementary school with the textbook currently in use. Interview techniques were conducted to find out firsthand the opinions of teachers and students about the needs of teachers and students to science textbooks based 3D Stereoscopic images. Interviews included questions on (1) textbooks used in the science lesson, (2) the conditions and constraints encountered with the use of textbooks currently in use, and (3) suggestions for improvements to textbook currently in use. Meanwhile, document studies are conducted to observe the textbook that is being used, the documents analyzed in the form of textbooks that are being used, textbooks analyzed based on conformity with core competencies, basic competencies, goals, and learning materials. 


\section{RESULT AND DISCUSSION}

\section{Literature Study}

Science learning process according to Semiawan [5] occurs by doing science where they learn not to be a spectator, but actively involved early on, in real experience. Science learning should provide hands-on experience to develop students' competence in understanding the natural environment scientifically. As revealed by Samatowa [6] that direct experience provides an important role as a driver of cognitive development of children and learning model suitable for Indonesian children is learning through direct learning (Learning by doing).

Piaget in [7] reveal that the intellectual development of children in elementary school age (7-11 years) still can't think either logically or abstractly. Children's way of thinking is limited to concrete, real, and definite things, a term that shows more real and concrete experiences than abstractions. Therefore, needed an atmosphere of learning in accordance with the students' thinking. If learning does not match the students' thinking stages then learning will become meaningless. This is because, in the learning process students are only trying to memorize the definitions so that students are having difficulty memorizing it, even though they already memorize it they can easily forget it because students do not understand what is being learned. Students are difficult to remember something because the material received was foreign because it is not related to the activities of daily life.

One of the concepts in science learning is the animal and plant morphology concepts. This learning discusses the characteristics of outer forms of animal and plant body according to their habitat. In the implementation of animal and plant morphology learning, it must be done in the nature of science learning for learning purposes that can be achieved. According to Toharudin et al. [2] science learning process has several essences that is, science as scientific work (process and procedure), science as a product, and science as a means of developing value / attitude. The three essences of the science should be obtained by students in learning. One of the most important things in teaching the nature of science learning that is contained in core competence and basic competence is textbook. Kurniasih and Sani [8] explained that the textbook is a material or subject matter written in the form of a book and used as a lesson material that became a source of learning information for students. The use of textbooks should be tailored to the needs of students in implementing learning.

Bhimwal [9] 3D stereoscopic images are images that use 3D imaging (3D) that work through the creation of the illusion of depth aspects in a particular image. Furthermore, it can be explained that the 3D stereoscopic image is an image created with an image where when the image is viewed with the right eye and the left eye will overlap with different colors. Science textbooks based 3D stereoscopic image will be able to present visual illustrations with three-dimensional (3D) concepts so that learning materials can be easily understood by elementary school students.

Joseph [10] explains 3D visualization is very useful for learning. 3D visualization tools tend to be most useful when demonstrating abstract concepts such as astronomy, or very small ones such as nanotechnology. Stereo visualization allows students to familiarize and see from a world that is difficult or impossible to experience real life. Garcia, Santana, and Molina [11] in his study entitled Using Effective 3D Stereoscopic 
Molecular Model Visualizations in Undergraduated Classroom. The research concludes using the use of Stereoscopic 3D images to visualize molecular models in chemistry learning, making learning effective. In addition, the results of a study conducted by Ferdig R, Blank J, Kratcoski A, and Clements R [12] used 3D stereoscopic images to teach complex science concepts. 3D Stereoscopic images can effectively be used to engage students with complex disciplinary content, because it is presented with informative representations of abstract concepts. In addition, it shows that demonstrating that stereoscopic 3D images can improve learning and retention in some educational materials, especially the concept of science. The phenomenon of science in 3D because they in real life allow users to relate this spatial relationship and easily understand the concepts of making the main connection between structure and function. Price [13] 3D stereoscopic images have the potential to benefit learning. The use of stereoscopic is used to make something unique.

The results of literature studies show that natural sciences is a learning process that provides direct experience for students, and elementary school students are students who are still in concrete operational thinking stage, so that in learning the concept of science primary school students need textbooks based on 3D stereoscopic images that are useful to help understand Abstract science concept.

\section{Field Studies}

In this section of the article, the field study findings are organized into three sections, starting with the interview to find out the science learning process with the commonly used textbook. Further research results from observation and document analysis are also discussed in this section.

\section{Interview}

Based on interviews with three elementary school teachers in Surakarta, it was found that the learning of animal and plant morphology concept has been using integrated thematic book referring to the 2013 curriculum provided by the government. So far textbooks into raw resources to support the learning process of teaching the concept of animal and plant morphology. In detail the results of the interview can be described as follows. 
TABLE I. RESULTS OF INTERVIEWS WITH TEACHERS ON THE USE OF SCIENCE TEXTBOOK

\begin{tabular}{|c|c|c|}
\hline$\overline{\text { No }}$ & Indicator & Discussion \\
\hline 1. & $\begin{array}{l}\text { Learning Materials } \\
\text { used in Science } \\
\text { Learning }\end{array}$ & $\begin{array}{l}\text { During the science lesson, using an integrated } \\
\text { thematic book published by Kemendikbud as the main } \\
\text { book, without any other companion books. The } \\
\text { textbook used also refers to the } 2013 \text { curriculum. }\end{array}$ \\
\hline 2. & $\begin{array}{l}\text { Views on the } \\
\text { conditions and } \\
\text { constraints of } \\
\text { textbooks used. }\end{array}$ & $\begin{array}{l}\text { Textbooks used less complete thematic presents the } \\
\text { concept of science learning and presents the image as } \\
\text { an illustration of the concept of science. So the teacher } \\
\text { has obstacles to the concept of science as a whole. }\end{array}$ \\
\hline 3. & $\begin{array}{l}\text { Suggestions for the } \\
\text { development of } \\
\text { textbooks required }\end{array}$ & $\begin{array}{l}\text { It takes other teaching materials as a supplement of the } \\
\text { main teaching materials, teaching materials can be a } \\
\text { book that presents the science concept in full and } \\
\text { accompanied by illustrations images in teaching } \\
\text { materials to facilitate students for understanding the } \\
\text { science concept. }\end{array}$ \\
\hline 4. & $\begin{array}{l}\text { A view on the } \\
\text { development of } \\
\text { textbooks based 3D } \\
\text { Stereoscopic images }\end{array}$ & $\begin{array}{l}\text { Teachers felt that the use of textbooks based on 3D } \\
\text { Stereoscopic images of science was felt to be in } \\
\text { accordance with the needs in science learning. This is } \\
\text { because the use of color images and three dimensions } \\
\text { (3D) in accordance with the characteristics of students } \\
\text { who are still in the stage of concrete thinking, so still } \\
\text { need the help of images to change the concept of } \\
\text { abstract into concrete. In addition, special textbooks } \\
\text { providing images relevant to the science materials } \\
\text { studied have never been used before. They believe if } \\
\text { using the book then the students will be better able to } \\
\text { master the concept of learning science because } \\
\text { through the textbook the material is presented more in } \\
\text { depth with the help of the pictures as an illustration. }\end{array}$ \\
\hline
\end{tabular}

Results of interviews with teachers shows that teachers and students in implementing learning requires additional textbooks. This necessity for an integrated thematic books used contains concepts that are not deep. So learning provided cannot fully answer the purpose of learning. In addition, students need textbooks that are made based on their thinking ability. 


\section{Observation}

Observation results on science learning activities in some schools in the Surakarta city. obtained an overview of science teaching conducted by teachers in the classroom more using the lecture method. In conveying the concept of science, teachers only refer to the textbook given by the national government as the main focus of learning, without developing other teaching materials that can sustain learning activities to achieve effective and efficient learning. In addition, the observation of student learning when he followed the lesson, students pay less attention to the delivery of material done by the teacher. Textbooks are only open without reading.

Based on observation during science lesson in grade IV of elementary school, student reaction to learning process still less enthusiastic. It is still a constraint during science learning that the participation of students during learning is still lacking and textbooks used in schools are still textbooks are colorless and incomplete. The Textbooks used are less able to attract students to learn, because it is not in accordance with the characteristics of students and the characteristics of learning materials that require an interesting image to illustrate the material being taught.

Observation result shows that thematic textbook has become the main thing in the learning process. Teachers teach and organize learning by using textbooks as learning resources. However, teaching materials used are still conventional because it only contains reading material and questions. The quality of science learning becomes low because it is only fixated on the textbook that is conventional. Therefore, the need for teaching materials that not only contains reading material and questions. As educators who have concern with students, it's not wrong if you want to do new exploration to develop new things that are not found in the learning process that has been used. Moreover, the science learning process requires a textbook concept that can present the abstract concepts to be concrete. This problem is used as a foundation for researchers to choose to develop science teaching textbooks for elementary school students based on Stereoscopic 3D images that can provide a concrete thing as a presentation of the concept of science in the textbook.

\section{Document Analysis}

Document analysis is carried out to observe the learning documents used, especially textbooks for learning. The analysis begins by identifying the suitability of core competencies, basic competencies, indicators, subject matter, and learning activity steps. In addition, the researchers also conducted an analysis of textbooks based on linguistics, legibility, content, and presentation of images in books.

Document analysis results show that the learning process uses syllabus and integrated learning plan. Textbooks used was a text book that is distributed by the national government. The textbook used has been prepared in accordance with the syllabus that has been determined. The learning concept about animal and plant morphology is contained in the textbook theme 3 Peduli Terhadap Makhluk Hidup. Animal and plant morphology concepts presented in this text in accordance with the curriculum used in the school. The language used in textbooks can be understood by students. However the concept in the textbook is incomplete, one of the examples seen in the textbook page 20, on the page is described as follows: 


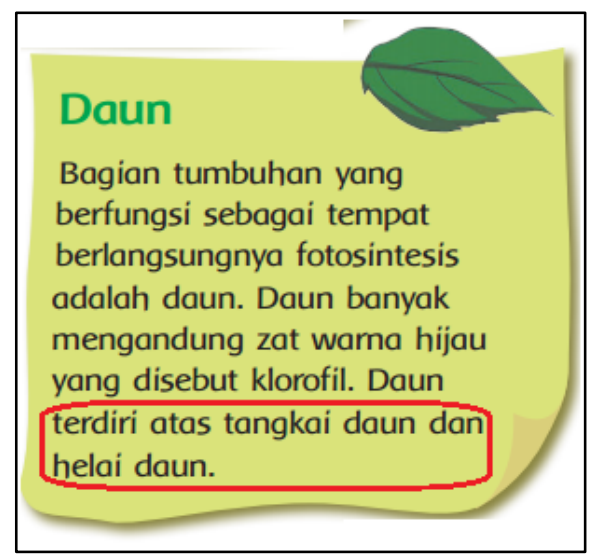

Figure 1. Examples of incomplete textbook concepts

From the explanation, the student will learn that the leaf part consists of petiole (tangkai daun), and blade (helai daun). In fact, the complete leaf consists of petiole (tangkai), stipule (dahan), and blade (helai daun). Should be given a more detailed description of the leaf as follows:

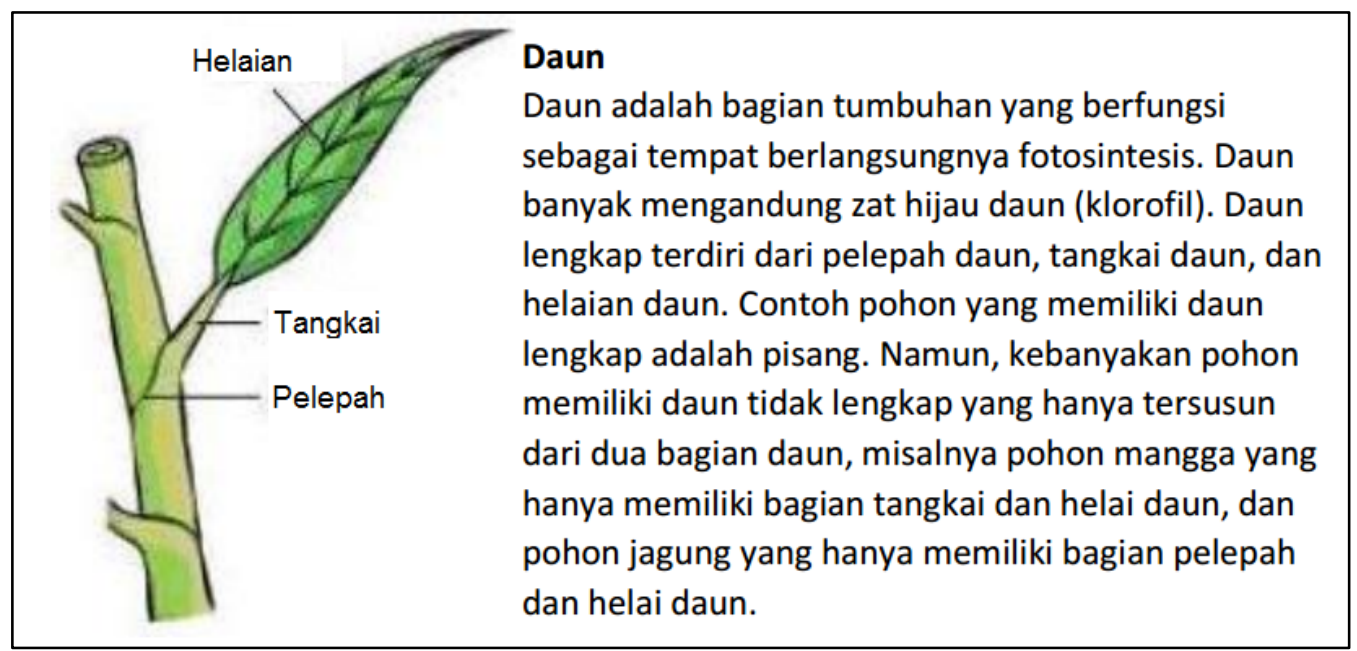

Figure 2. Examples of improvements to the concept of textbook content

If the textbook gives a more detailed explanation, then students will be able to know the complete leaf part. Because not all plants have complete leaf parts. In addition, textbooks are lacking in complete drawings that support the concept of animal and plant morphology. Whereas the presentation of images in textbooks can be used as an illustration of concepts that can help students to mastery the concept of science. 


\section{CONCLUSION}

Based on the research data, it can be concluded that the science textbook based on $3 \mathrm{D}$ stereoscopic image is required as a supplement book on the learning process to support the mastery of learning concepts. The textbook need to be developed as they can be used as a companion teaching material from existing integrated thematic textbooks. Textbooks based on 3D stereoscopic images will make it easier for students to understand the concept of science, because through the images in the book, the concept of learning is no longer in the form of abstract. Textbooks based on stereoscopic 3D images will make it easier for students to understand the concept of science, because through the images in the book, the learning concept will be concrete. Textbooks developed based on the characteristics of elementary school students will be able to attract students 'interest to learn so as to enhance students' conceptual understanding. This study is used as a preliminary study to carry out research and development of textbooks that can meet the needs of teachers and elementary school students in implementing science learning.

\section{REFERENCES}

[1] Wisudawati, A., \& Sulistyowati, E. 2014. Metodologi Pembelajaran IPA. Jakarta: Bumi Aksara.p.22.

[2] Toharudin, U. et, al. 2011. Membangun Literasi Sains Siswa. Bandung: Humaniora.pp.27-28.

[3] Situmorang. 2014. Efektivitas Modul Pembelajaran Inovatif untuk Meningkatkan Hasil Belajar Pada Pengajaran Laju Reaksi. Jurnal Penelitian Bidang Pendidikan. 20 (2). pp.139-147.

[4] Ardenghi, L, Pozer,. \& Roth, Wolff Michael. 2015. Memahami Alat-Alat Bantu Visual dalam Buku-Buku Teks Sains. in Tobin, Kenneth (Editor) Handbook Pengajaran dan Pembelajaran Sains. New York:Praeger Publishing. pp.106-114.

[5] Semiawan, C.R. 2008. Belajar dan Pembelajaran Prasekolah dan Sekolah Dasar. Jakarta: PT. Indeks.p.104.

[6] Samatowa, U. 2011. Pembelajaran IPA di Sekolah Dasar.Jakarta:Indeks.p.5.

[7] Danim, Sudarwan., \& Khairil. 2013. Psikologi Pendidikan. Bandung:Alfabeta.p.78.

[8] Kurniasih, Imas,. \& Sani, Berlin. 2014. Panduan Membuat Bahan Ajar Buku Teks Pelajaran. Surabaya:Kata Pena.pp.85-86.

[9] Bhimwal, Amitoz. 2011. Stereoscopic: A Seminar Report. Jaipur: Departement of Information Technology.

[10] Joseph, Norman. 2011. Stereoscopic Visualization as a Tool for Teaching Astronomy Concepts. (Thesis) Department of Computer Graphics Technology, Purdue University. West Lafayette, Indiana.

[11] Garcia-Ruiz, M. A., Santana, P. C., \& Molina, I . 2014. Using Effective 3D Streoscopic Molecular Model Visualizations in Undergraduated Classroom. International Jurnal for CrossDisciplinary Subjects in Education (IJCDSE). V(I). pp.1593-1598.

[12] Trindade, J., Fiolhais, C., \& Almeida, L. 2002. Science learning in virtual environments: a descriptive study. British Journal of Educational Technology,33(4), pp.471-478.

[13] Price,et.al. 2015. Position Paper on Use of Stereoscopic to Support Science Learning. Journal of Astronomy \& Earth Sciences Education. II(I). pp.17-25. 